\title{
Software development to support decision making in the selection of nursing diagnoses and interventions for children and adolescents ${ }^{1}$
}

\author{
Kenya de Lima Silva² \\ Yolanda Dora Martinez Évora ${ }^{3}$ \\ Camila Santana Justo Cintra ${ }^{4}$
}

\begin{abstract}
Objective: to report the development of a software to support decision-making for the selection of nursing diagnoses and interventions for children and adolescents, based on the nomenclature of nursing diagnoses, outcomes and interventions of a university hospital in Paraiba. Method: a methodological applied study based on software engineering, as proposed by Pressman, developed in three cycles, namely: flow chart construction, development of the navigation interface, and construction of functional expressions and programming development. Result: the software consists of administrative and nursing process screens. The assessment is automatically selected according to age group, the nursing diagnoses are suggested by the system after information is inserted, and can be indicated by the nurse. The interventions for the chosen diagnosis are selected by structuring the care plan. Conclusion: the development of this tool used to document the nursing actions will contribute to decision-making and quality of care.
\end{abstract}

Descriptors: Nursing Informatics; Nursing Process; Software; Information Systems.

\footnotetext{
${ }^{1}$ Paper extracted from doctoral dissertation "Software Development for Identifying Nursing Diagnoses and Interventions", presented to Escola de Enfermagem de Ribeirão Preto, Universidade de São Paulo, PAHO/WHO Collaborating Centre for Nursing Research Development, Ribeirão Preto, SP, Brazil. Supported by Conselho Nacional de Desenvolvimento Científico e Tecnológico (CNPq), Brazil, process \# 306916/2009-6.

2 PhD, Professor, Centro de Ciências da Saúde, Universidade Federal da Paraíba, João Pessoa, PB, Brazil.

${ }^{3}$ PhD, Full Professor, Escola de Enfermagem de Ribeirão Preto, Universidade de São Paulo, PAHO/WHO Collaborating Centre for Nursing Research Development, Ribeirão Preto, SP, Brazil.

${ }^{4}$ Master's student, Escola de Enfermagem de Ribeirão Preto, Universidade de São Paulo, PAHO/WHO Collaborating Centre for Nursing Research Development, Ribeirão Preto, SP, Brazil.
}

Corresponding Author: Kenya de Lima Silva

Universidade Federal da Paraíba

Departamento de Enfermagem em Saúde Pública e Psiquiatria

Cidade Universitária

Bairro: Castelo Branco

CEP: 58051-900, João Pessoa, PB, Brasil

E-mail: kenya.cateq@gmail.com
Copyright () 2015 Revista Latino-Americana de Enfermagem This is an Open Access article distributed under the terms of the Creative Commons Attribution Non-Commercial License (CC BY-NC).

This license lets others distribute, remix, tweak, and build upon your work non-commercially, and although their new works must also acknowledge you and be non-commercial, they don't have to license their derivative works on the same terms. 


\section{Introduction}

The Ministry of Science and Technology (MST) has launched strategies that propose the aggregation of new elements to the work, education and research environments by means of the use of Information and Communications Technology (ICT). It also establishes as a priority the translation of scientific and technological developments in order to develop areas that have more direct impact on the living standards of the population(1).

In addition to these challenges, the National Hospital Care Policy and the Health Care Network Policy (HCNP) aim to incorporate health technologies and qualify labor processes in order to reorganize hospital services in the Unified Health System (UHS), from a perspective of continuing care, thereby reaffirming the need to share information so that it can contribute to the spread of knowledge among the UHS professionals, and quality of care to the population (2).

As for the development of technology for health, the electronic health record has been been shown to allow immediate access to information(3). The records are: more accessible, readable, easily retrieved(4); improve efficiency, quality of care, and communication speed; and, able to avoid duplication of information ${ }^{(5)}$.

Given the significant amount of information produced by nursing professionals during patient care, associated with COFEn Resolution no. 358/2009(6), which establishes the obligation of Nursing Care Operationalization (NCO) in all health care services, the importance of developing electronic nursing records is evident. However, they must be a reflection of the nursing process (NP) in order to direct and structure documentation, considering the specific legislation.

The insertion of the electronic records into the reality of patient care has stimulated the development of several nursing systems. With that aim, standardized terminologies that facilitate the exchange of information are necessary, namely terms that constitute a framework that articulates with other existing systems within the service. A study on the cross-mapping between the International Classification for Nursing Practice (ICNP ${ }^{\circledR}$ ), version 1.0, and the Systematized Nomenclature of Medicine Clinical Terms (SNOMED-CT) showed that $80 \%$ of the ICNP $^{\circledR}$ terms are present in SNOMED-CT(7). In addition, ICNP ${ }^{\circledR}$ has been recommended by the International Council of Nurses (ICN), to be used in care and included in information systems.

In Brazil, some experiences with the development of electronic nursing records can be highlighted, such as PROCEnf - USP (Electronic System for the Nursing Process Documentation of the University of São Paulo USP) ${ }^{(8)}$, which uses NANDA International; the inclusion of the nursing process within a Personal Digital Assistant (PDA) for the care of patients in the Intensive Care Unit in the Hospital of the Federal University of Santa Catarina, which uses the ICNP ${ }^{\circledR(9)}$; and the PDA access to the nursing process based on a list of problems ${ }^{(10)}$. However, there is a concentration of studies in specific regions of the country, such as the South and the Southeast ${ }^{(11)}$, thereby evidencing the digital gap when one thinks of electronic nursing records at the national level, and the gap of these technologies in the northeastern reality.

The integration of ICT into nursing practice has caused changes not only to the record, but also to the work and the relationship between the nurse and the patient, in the context of practice and communication with families ${ }^{(12)}$. It should be noted that the Electronic Health Record (EHR) provides nurses with more competent management of care, because it assists in supporting decision-making ${ }^{(13-14)}$. Moreover, it can assist in education by encouraging students to become more involved with the care.

There is a gap in the literature regarding software development to support decision making in the identification of nursing diagnoses and interventions in the care of children and adolescents using the ICNP ${ }^{\circledR}$. Therefore, we believe that the software developed in this study will be able to contribute to populate a database with information that will enable assessing the status of hospitalized children and adolescents, thereby enabling assessment of the nursing team's actions in the recovery process, and the applicability of nursing diagnoses and interventions labels developed from the ICNP ${ }^{\circledR}$.

The objective of this study was to report the development of software to support decision-making for the selection of nursing diagnoses and interventions for children and adolescents, based on the nomenclature of nursing diagnoses, outcomes and interventions of a university hospital in Paraiba.

\section{Method}

This was an applied study.

The software was designed to be used in the Pediatric Clinic of a teaching hospital in the city of João Pessoa, Paraíba, which exclusively admits UHS patients.

The methodological steps used were based on software engineering, as proposed by Pressman, ${ }^{(15)}$ and grounded on the systems development life cycle. This 
model begins with planning, initially structured through communication with the client, then a risk analysis is performed to begin engineering (modeling and construction). After this phase, the produced material is sent out to be tested by the client and continues again towards planning, to restart the cycle.

\section{First cycle}

Planning/risk analysis: to set the system functionality, a flow chart was designed to visualize the sequence of activities and the flow of information to guide the development of the programming algorithm, responsible for the connection between the real world and the world of computational logic.

Engineering/testing: by using the Unified Modeling Language (UML), the flow chart was designed with the help of JUDE System Design Tool, and its functionality was analyzed.

\section{Second cycle}

Planning/risk analysis: to convert ideas into images, the screen interface was structured. The data collection phase was built, constructed by converting the instruments used in the service into screens. In addition, administrative screens were prepared (user and patient registration, visualization of inpatient stay, patient admission, visualization of previous hospitalizations, and inpatient selection) and other screens to display the diagnoses, select the interventions, display the care plan, and evaluate care.

The nursing diagnoses and interventions entered in the system have been validated with the help of experts in a previous study, which make up the nomenclature of diagnoses/outcomes and interventions of the Pediatric Clinic in a university hospital(16), developed from the International Classification for Nursing Practice.

Engineering/verification: the Axure $\mathrm{RP}^{\circledR}$ software was used (a design and layout tool to create diagrams, wireframes, prototypes and website specifications) to develop the navigational interface of the screens and facilitate viewing of the nursing process.

\section{Third cycle}

Planning/risk analysis: construction of functional expressions to structure the programing, based on the indicators of the data collection instruments, and to direct the displaying of nursing diagnoses by the system.
Engineering/verification: for the system development, open access (open source) software was used - Eclipse, which is an Integrated Development Environment (IDE); Zend and MySQL Workbench. The system was developed with PHP + MySQL language, along with P4A language (PHP for Application). With regard to information security, it gives access to data only to users with a Nursing Regional Council (COREN) number that is previously registered by the administrator. In addition, the software was installed on a network server with encrypted passwords, in order to expand the entry security system and facilitate the simulation tests. The whole software development process and implementation on the network server occurred between March 2012 and January 2014.

The study met the ethical standards, was approved with Protocol N.486/2011 and is registered in the National Information System on Ethics in Research Involving Human Beings (SISNEP) with CAAE-0257.0.126.153-11.

\section{Results}

To develop a software prototype, knowledge on the NPO, nursing practice, classification systems and programming logic were united, and it was indispensable to determine what functions the client (researcher) expect from the software. As a result, it was necessary to define with the programmer the sequence of activities that the system should accomplish, considering the steps of the nursing process and the program's responsiveness, which culminated in the construction of the flowchart (Figure 1).

Next, with the help of Axure RP ${ }^{\circledR}$ software, the system called SISPED was structured, consisting of an access login for the nursing professional, professional registration, user registration, search for registered patients, inpatient viewing, patient admission, visualization of previous hospitalizations, inpatient selection, performance of data collection (instrument automatically selected by the system by age group), access to hospitalized patients (Figure 2). The system also enables the performance of new data collection, visualization of the nursing assessment, diagnosis(es) and care plan, in addition to selecting the diagnoses among those suggested by the system, selecting interventions and exhibiting the care plan and evaluation.

Once the administrative screens were constructed, the nursing process construction phase started. With that aim, the data collection instruments for children from birth to five years old and adolescents are converted to 
SISPED screens. To facilitate the use, simple interfaces were constructed, which reflect the reality of care and maintain the characteristics of validated instruments. The screens were constructed considering the sequence of basic human needs in the instruments and the next phases of the nursing process. Figure 3 shows, as an example, the screen on the nutritional needs of the nursing history.

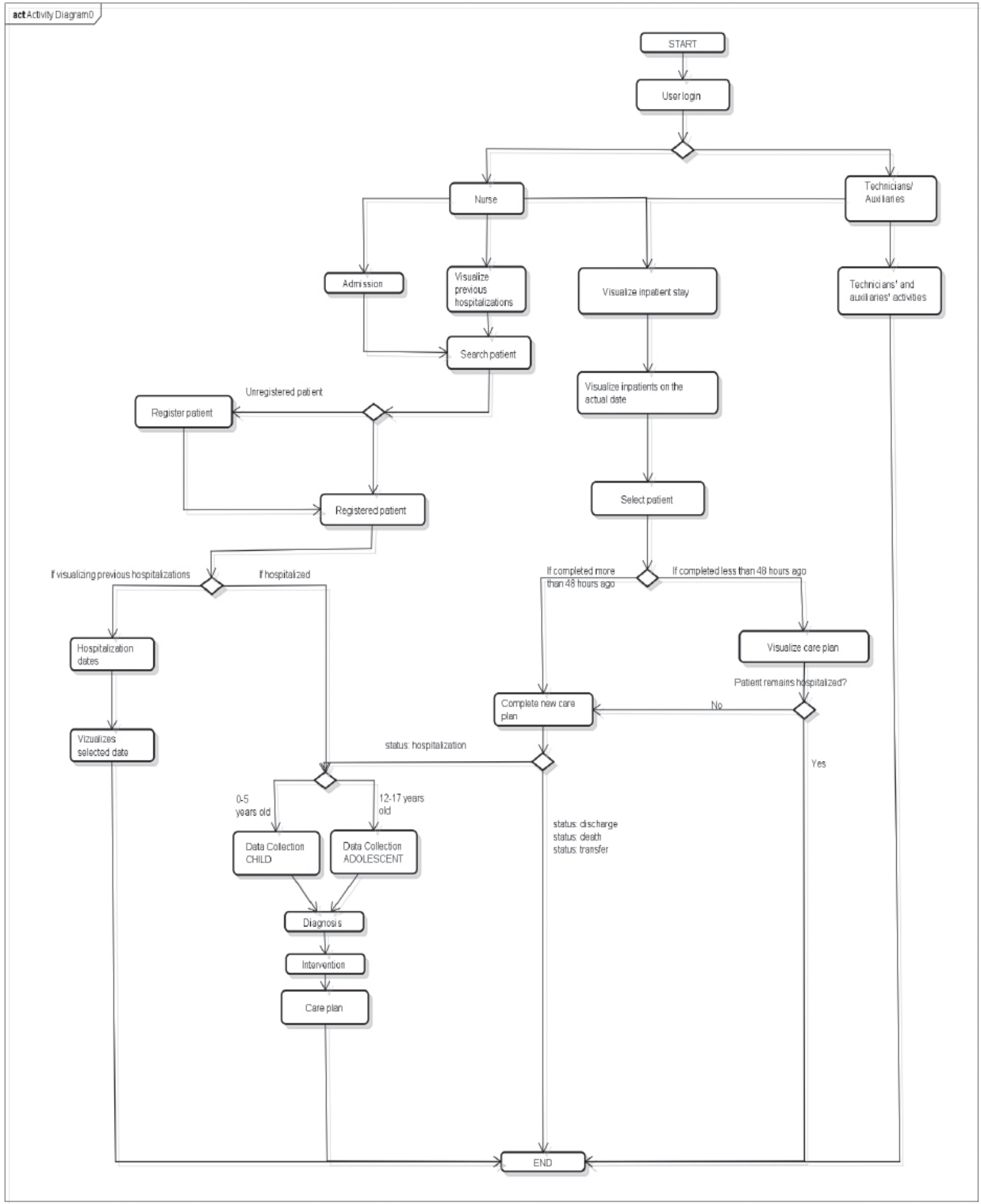

Figure 1 - Functional software flowchart 


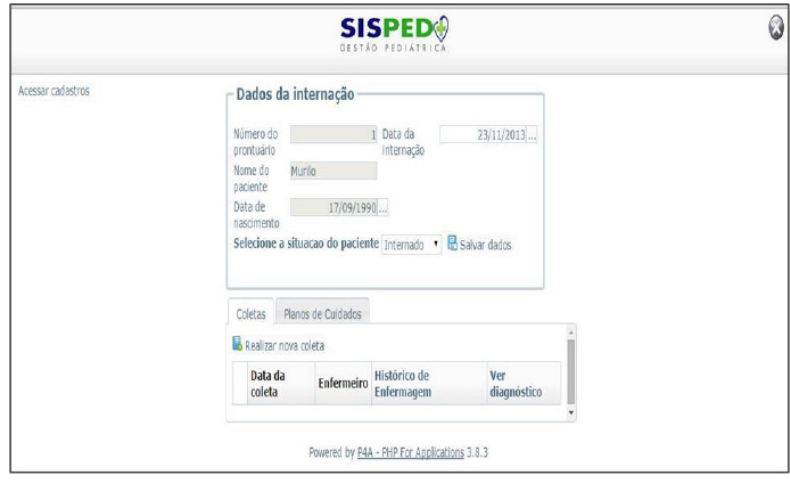

Figure 2 - Access screen to inpatient

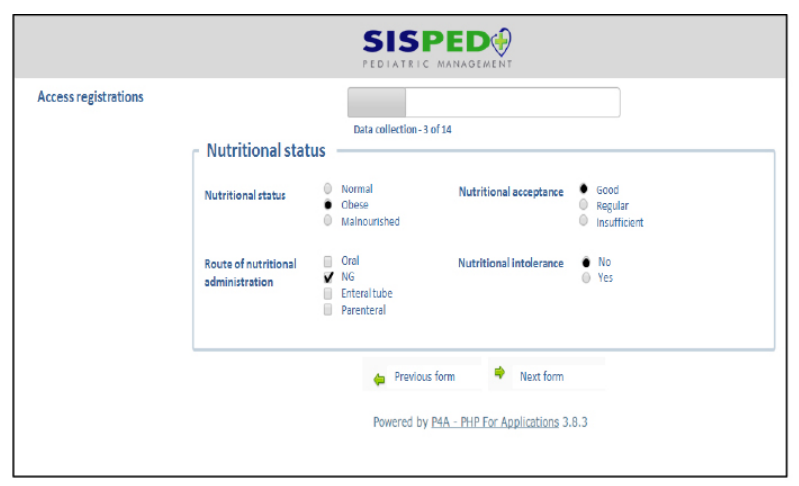

Figure 3 - Nursing history screen (nutritional needs)

Once determined what the system should present and how to do it, the way to convert these data into programming must be defined. Thereby, it was necessary to materialize the algorithm of the reasoning process by using indicators of the instruments (terms in the instruments used for data collection) and the diagnosis titles validated for the service, from the ICNP ${ }^{\circledR}$ terms, in order to structure the programming algorithm to support decision-making.

In order to aid the software programming, 236 functional expressions (grouping of indicators that can direct a nursing diagnosis) were created so that the system would contribute to decision-making on nursing diagnoses. An example of a functional expression for the nursing diagnosis, "impaired gas exchange", is presented - [breathing (tachypnea or bradypnea or dyspnea)] + [auscultation (rhonchi and/or wheezing)] + [cough (dry or chesty without sputum or chesty with sputum)] + [cyanosis (lip and/or nail) + (nasal flaring and/or intercostal retractions)].

The software was programmed so that modifications can be entered, including new diagnoses and adaptations to the existing ones. Figure 4 shows, as an example, a screen of nursing diagnoses after entering patient information.

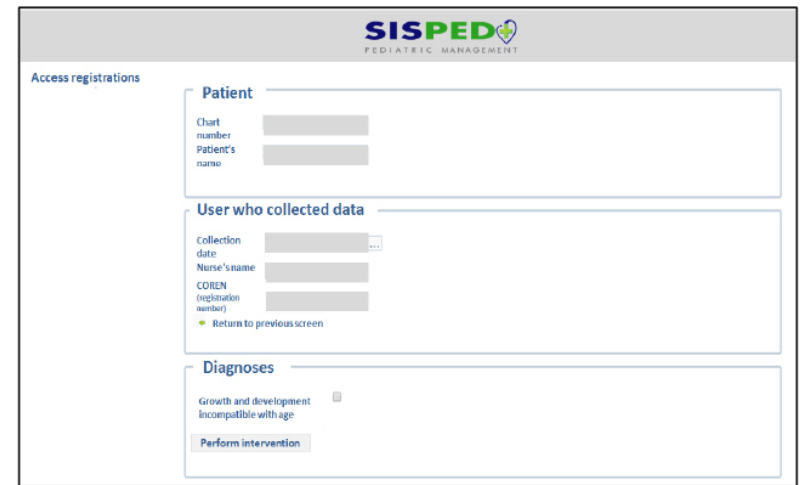

Figure 4 - Diagnostic suggestion screen

After defining how the SISPED would display the diagnoses, possible interventions were entered (Figure 5 ). Considering that the system was under construction for the service, programming was developed by inserting 616 interventions of the Diagnosis/Outcomes and Interventions nomenclature of the institution. Thereby, the system displays for selection interventions that have been validated, with the possibility of the nurse selecting those most suited to the patient's status.

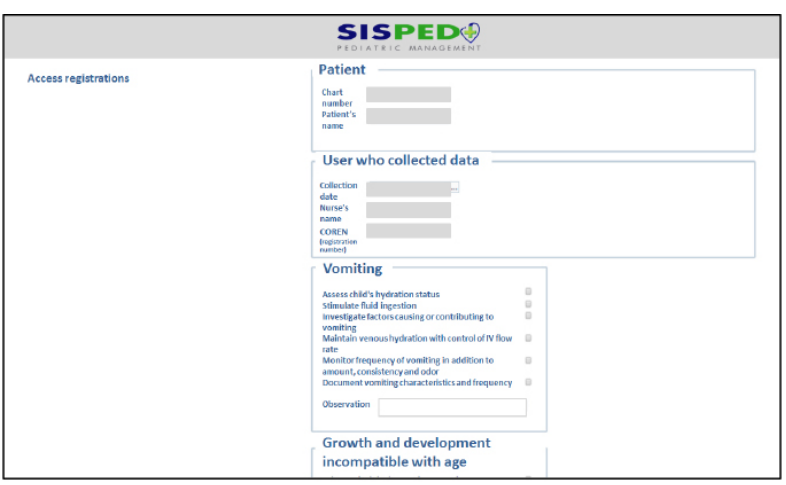

Figure 5 - Intervention suggestion screen

\section{Discussion}

The challenge for developing the software is to maintain the balance between the different types of knowledge, i.e., the nursing classification systems, the nursing process and the computational logic, because lack of familiarity can lead to errors. In addition, rushing the construction of technological elements can lead to mistakes and dissatisfaction of the end user(15).

From this perspective, the modeling tools can be used to represent how the system will perform its functions. They also serve as a guide to understanding the flow of information and directing the construction in order to improve the product quality and process ${ }^{(15)}$. In the information flowchart, developed for this study, we used the UML language, which facilitates understanding 
of the system and its interface. By using the UML, information must be made easy for users, with little graphical notations and more intuitive signals to prevent visual pollution(17).

The implementation of the Electronic Health Record is challenging because it causes changes and can lead to resistance. Therefore, an information flow must be developed to facilitate its use, understanding and team communication.

In this study, the screens constructed for the prototype were configured to facilitate user understanding regarding the use of the system and operationalization of the nursing care in order to prevent visual pollution, data duplication, and to establish a pattern to facilitate the final design of the system.

Studies investigating the use of the EHR have identified problems in the man/machine relationship, especially: data entry into the system, the lack of feedback between machine/man on data entry, systems that do not conform to the hardware, problems with navigation, and excessive information on the screen or information irrelevant for practice, which overload documentation and lead to user resistance(18-19).

By transporting these ideas to a technology that aims at documenting nursing actions, it is important to remember that concerns about the terms and concepts can be minimized with the use of a theory to guide the lenses through which care is seen, validated data collection instruments and classification systems that reflect the care reality. Thus, the use of an instrument that considers the specificity of the investigated population contributes to the diagnostic reasoning process, and therefore with more effective care.

In the present study, the indicators inserted in the nursing history screens were transported from instruments validated by the institution under study. These instruments are significant for nursing care and provide data to guide nurses' clinical decisions and collaborate to implement changes in caring, doing and teaching in nursing(20). These instruments helped construct the functional expressions and contributed to the standardization of information, providing data to structure the programming.

When the clinical data recorded by the nursing team are normalized in a grading system, they can support the development of integrated systems for the construction of the patient's chart, support the development of clinical decision systems, and be a source to aid syntactic and semantic interoperability of the system ${ }^{(21)}$.
To support decision-making, the EHR must be structured with a standardized architecture for the system to provide the professional with more competent management of patient care ${ }^{(14)}$. Standardized terminologies should also be used to give support to the archetypes so that they can be associated with controlled vocabularies ${ }^{(22)}$, such as, for example, ICNP ${ }^{\circledR}$, SNOMED-CT, NANDA-I, among others.

Archetypes are computable expressions of a concept in the domain level, in the form of declaring structured restrictions, based on a reference model of training(22). In this study, functional expressions to direct the nursing diagnoses were prepared. The knowledge base to build archetypes must be created and adapted by clinicians, such as nurse specialists ${ }^{(23)}$.

It should be noted that models must be created to structure the archetypes, since there is no terminology covering all concepts used in healthcare. Thereby, the models enable systematically creating and organizing clinical information or knowledge in specific contexts to meet the data capture requirements. However, the data do not need to be in a standard model; they can be mapped among the systems ${ }^{(24)}$. A previous study mapping the same terms in free texts of nursing and medical records in the electronic charts of patients admitted for gastrectomy found that $32.3 \%$ of the terms could be mapped to the SNOMED-CT and ICNP ${ }^{\circledR(25)}$. This means that data from electronic nursing and medical modules can be shared even by systems using different terminologies.

In the construction of systems to support decisionmaking, the presence of professionals with experience in the software application area are essential to structure a system supporting professionals in care practice, without however, inducing them to incorrect diagnosing, as the system is a support tool to aid the professional. In this sense, the reasoning process as a judgment activity, requires skills and experience from the nurse that are essential to define the focus of care and individualize it. In this study, the system was structured to make suggestions of possible diagnoses.

The use of software to aid documentation of care can help both nursing professionals and students in the development of clinical judgment and the diagnostic reasoning process. It also helps in the assessment of diagnostic accuracy and improves the quality of care.

The difference in this software is the display of diagnoses developed by the system through the entered data, thereby increasing the probability of providing more coherent and targeted care. However, 
the response interpretation, namely, the process of reasoning and deciding on which diagnosis is appropriate for the patient's condition, is the nurse's responsibility.

There are countless consequences from this software, including the possibility of providing the service with a technology that can favor the patients' return to home and to the primary care unit, since the care plans can be transferred across services when the system is networked. The lack of a networking system does not prevent these actions, because when the care plan is printed, it can help caregivers and family follow up with the care.

The limitations of this study are the need for testing usability and quality in use, since the tests with the system were performed in simulated environments. Overcoming this phase can lead to errors both in the workflow and in the information efficiency. Another point to be noted is the system's failure to present results. However, considering that the ICNP $^{\circledR}$ is a combinatorial terminology, the results can be proposed from an improved judgment of the identified diagnosis.

\section{Conclusion}

The purpose of this study was to develop software to support decision-making in the selection of nursing diagnoses and interventions for children and adolescents.

The screens constructed for the prototype were configured to facilitate user understanding regarding the use of the system and the operationalization of nursing care, in order to prevent visual pollution, data duplication and set a standard to facilitate final system design. In this study, the indicators inserted in the nursing history screens were transported from validated instruments for the institution under study. These indicators aided the development of functional expressions, thereby contributing to the standardization of information and providing data for programming structuring.

The use of software to aid documentation of care can help both nursing professionals and students in the development of clinical judgment and diagnostic reasoning process. It also contributes to the assessment of diagnostic accuracy, thereby improving the quality of care.

The differential characteristic of this software is the display of diagnoses developed by the system from the entered data, thereby increasing the likelihood of more coherent and targeted assistance.
We sought a system that would be more than a tool to document the nursing actions, a support for decisionmaking in order to contribute to the quality of care.

\section{References}

1. Batista AJS, Pepe VLE. Os desafios da nanotecnologia para a vigilância sanitária de medicamentos. Ciênc Saúde Coletiva. [Internet]. 2014 [acesso 18 fev 2015];19(7):2105-14. Disponível em: http://www.scielo.br/pdf/csc/v19n7/1413-8123csc-19-07-02105.pdf

2. Silva RMM, Viera CS. Acesso ao cuidado à saúde da criança em serviços de atenção primária. Rev Bras Enferm. [Internet]. 2014 out [acesso 18 fev 2015];67(5):794802. Disponível em: http://www.scielo.br/pdf/reben/ v67n5/0034-7167-reben-67-05-0794.pdf

3. Baillie L, Chadwick S, Mann R, Brooke-Read M. A survey of student nurses' and midwives' experiences of learning to use electronic health record systems in practice. Nurse Educ Pract. 2013;13(5):437-41.

4. Sheikh A, Cornford T, Barber N, Avery A, Takian $A$, Lichtner $V$ et al. Implementation and adoption of nationwide electronic health records in secondary care in England: final qualitative results from prospective national evaluation in "early adopter" hospitals. $\mathrm{Br}$ Med J. [Internet]. 2011 [acesso 23 jul 2013];343:d6054. Disponível em: http://dx.doi. org/10.1136/bmj.d6054

5. Zwaanswijk M, Verheij RA, Wiesman FJ, Friele RD. Benefits and problems of electronic information exchange as perceived by health care professionals: an interview study. BMC Health Services Research. [Internet]. 2011 Out [acesso 30 abr 2013];11:256. Disponível em: http://www.biomedcentral.com/content/pdf/14726963-11-256.pdf.

6. Resolução 358/2009 (COFEn). Dispõe sobre a sistematização da assistência de enfermagem e a implementação do processo de enfermagem em ambientes, públicos ou privados, em que ocorre o cuidado profissional de enfermagem. [Internet]. 15 out 2009. [acesso 30 set 2011]. Disponível em: http:// novo.portalcofen.gov.br/resoluo-cofen-3582009_4384. html

7. Park H-A, Lundberg C, Coenen A, Konicek D. Evaluation of the Content Coverage of SNOMED CT Representing ICNP Seven-axis Version 1 Concepts. Methods of Information Medicine [Internet]. 2011 [acesso 30 jul 2012]. 50(5):472-478. Disponível em: http://dx.doi. org/10.3414/ME11-01-0004 
8. Peres HHC, Cruz DALM, Lima AFC, Gaidzinski RR, Ortiz DCF, Trindade MM et al. Desenvolvimento de Sistema Eletrônico de Documentação Clínica de Enfermagem estruturado em diagnósticos, resultados e intervenções. Rev Esc Enferm USP [Internet]. 2009 [acesso 12 set 2014]; 43(spe2): 1149-55. Disponível em: http://www. scielo.br/pdf/reeusp/v43nspe2/a02v43s2.pdf

9. Barra DCC, Dal Sasso GTM. Tecnologia móvel à beira do leito: processo de enfermagem informatizado em

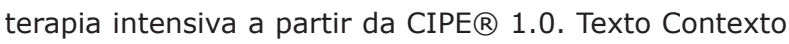
Enferm. [Internet]. 2010 [acesso 28 set 2011];19(1):5463. Disponível em: http://dx.doi.org/10.1590/S010407072010000100006.

10. Sperandio DJ, Évora YDM. Planejamento da assistência de enfermagem: proposta de um software-protótipo. Rev. Latino-Am. Enfermagem. [Internet]. 2005 [acesso 23 mar 2013];13(6):93743. Disponível em: http://dx.doi.org/10.1590/S010411692005000600004 .

11. Melo ECA, Enders BC. Construção de sistemas de informação para o processo de enfermagem: uma revisão integrativa. J Health Informatics [Internet]. 2013 [acesso 30 de jan de 2014]; 5(1):23-9. Disponível em: http://www.jhi-sbis.saude.ws/ojs-jhi/index.php/ jhi-sbis/article/view/233

12. Dowding DW, Turley M, Garrido T. The impact of an electronic health record on nurse sensitive patient outcomes: an interrupted time series analysis. J Am Med Informatics Assoc. [Internet]. 2012 [acesso 30 abr 2013];19(4):615-20. Disponível em: doi:10.1136/ amiajnl-2011-000504

13. Peres HHC, Cruz DALM, Lima AFC, Gaidzinski RR, Oliveira NB, Ortiz DCF et al. Avaliação de sistema eletrônico para documentação clínica de enfermagem. Acta Paul Enferm. [Internet]. 2012 [acesso 30 abr 2013];25(4):543-548. Disponível em: http://dx.doi. org/10.1590/S0103-21002012000400010.

14. Topaz M, Radhakrishnan K, Masterson R, Bowles KA. Putting evidence to work: using standardized terminologies to incorporate clinical practice guidelines within homecare electronic health records. Online J Nurs Informatics. (OJNI) [Internet]. 2012 [acesso 30 abr 2013];16(2). Disponível em: http://ojni.org/ issues $/ p=1694$

15. Pressman RS. Engenharia de software: uma abordagem profissional [Internet]. 7th ed. Porto Alegre: AMGH; 2011.

16. Marques DKA, Silva $\mathrm{KL}$, Nóbrega $M M L$, Nóbrega RV, Souza GLL, Bezerra PAPL, et. al. Diagnósticos, resultados e intervenções de enfermagem para crianças e adolescentes da clínica pediátrica. In: Nóbrega MML organizador. Diagnósticos, resultados e intervenções de enfermagem para clientes hospitalizados nas unidades clínicas do HULW/UFPB utilizando a CIPE $®$. João Pessoa: Idéia; 2011. p. 111-48.

17. Gomes LGO, Pereira AF. Identificação de pontos de controle no ciclo de desenvolvimento de produto por meio de modelagem conceitual e mapeamento da informação. Gestão e Produção. [Internet]. 2014 [acesso 12 set. 2014]; 21(2):257-269. Disponível em: http://www.scielo.br/pdf/gp/v21n2/v21n2a04.pdf

18. Rogers $M$, Sockolow PS, Bowles $\mathrm{KH}$, Hand $\mathrm{KE}$, George J. Use of a human factors approach to uncover informatics needs of nurses in documentation of care. Int J Med Informatics [Internet]. 2013 [acesso 30 nov 2013];82(11):1068-74. Disponível em: http://dx.doi. org/10.1016/j.ijmedinf.2013.08.007

19. Sandefer R, Brinda D, Wapola J, Maki SE, Marc D. EHR usability on mobile devices. Online Res J Educ Perspectives Health Informatics Information Manage. [Internet]. 2013 [acesso 01 out 2013];Summer:1-11. Disponível em: http://eduperspectives.ahima.org/ehrusability-on-mobile-devices/\#.U8RfupRdUYk

20. Ramalho Neto JM, Fontes WD, Nóbrega MML. Instrumento de coleta de dados de Enfermagem em unidade de terapia intensiva geral. Rev Bras Enferm. [Internet]. 2013 [acesso 30 nov 2013];66(4):53542. Disponível em: http://dx.doi.org/10.1590/S003471672013000400011.

21. Horsky J, Schiff GD, Johnston D, Mercincavage L, Bell D, Middleton B. Interface design principles for usable decision support: a targeted review of best practices for clinical prescribing interventions. J Biomed Informatics. 2012 [acesso 30 nov 2013] Dec; 45(6):1202-16. Disponível em: doi: http://dx.doi.org/10.1016/j. jbi.2012.09.002

22. International Organization for standardization (ISO). Int Electrotech Comm. ISO/TR 20514 - health informatics - electronic health record: definition, scope and context; 2005.

23. Kim YA, Park H-A. Development and Validation of Detailed Clinical Models for Nursing Problems in Perinatal care. Appl Clin Informatics. [Internet]. 2011 [acesso 30 abr 2013]; 22;2(2):225-39. Dsiponível em: doi: 10.4338/ACI-2011-01-RA-0007.

24. Delaney $B C$, Peterson KA, Speedie S, Taweel A, Arvanitis TNA, Hobbs FDR. Envisioning a learning health care system: the electronic primary care research net. work, a case study. Annals Fam Med. [Internet]. 2012 [acesso 30 abr 2013];10(1):54-9. Disponível em: 
http://www.annfammed.org/content/10/1/54.full. pdf + html

25. So E-Y, Park H-A. Exploring the possibility of information sharing between the medical and nursing domains by mapping medical records to SNOMED CT and ICNP. Healthcare Informatics Res. [Internet]. 2011 [acesso 30 abr 2013];17(3):156-61. Disponível em: http://dx.doi.org/10.4258/hir.2011.17.3.156 